\title{
MAHATMA GANDHI DAN GERAKAN PEREMPUAN DI INDIA
}

\author{
Kamaruddin Salim \\ Fakultas Ilmu Sosial dan Ilmu Politik \\ Universitas Nasional \\ kamaruddinslm@gmail.com
}

\begin{abstract}
ABSTRAK
Ahimsa dan Satyagraha merupakan puncak dari perjuangan Gandhi. Ahimsa dan Satyagraha mengkombinasikan tujuan jangka pendek dengan perspektif jangka panjang, yang lebih penting lagi Satyagraha membuktikan kebenaran metodanya untuk mempersatukan teori dengan cara-cara pergerakan sosial pantang kekerasan. Satyagraha membuktikan kekuatan metode Gandhi untuk melakukan penetrasi kepada rakyat walaupun di daerah-daerah agraris yang terkebelakang secara sosial dan politik, dan metodenya untuk melakukan pendekatan kolektif dan pendidikan gerakan sosial bagi perempuan. Ini adalah strategi untuk menanamkan disiplin dan keterlibatan aktif kaum perempuan dalam pergerakan sosial-politik dan ekonomi di India. Bagi Gandhi, terlibatnya kaum perempuan merupakan kegiatan terhormat bagi mereka.
\end{abstract}

Kata kunci: Ahimsa, Satyagraha, dan Gerakan Perempuan

\begin{abstract}
Ahimsa and Satyagraha were the culmination of Gandhi's struggle. Ahimsa and Satyagraha combine short-term goals with long-term perspectives, more importantly Satyagraha proves the correctness of his method to unite theory with ways of social movement abstinence from violence. Satyagraha proved the strength of the Gandhi method to penetrate the people even though in agrarian areas that were socially and politically underdeveloped, and methods for carrying out a collective approach and education of social movements for women. This is a strategy to instill discipline and active involvement of women in socio-political and economic movements in India. For Gandhi, the involvement of women was an honorable activity for them.
\end{abstract}

Key words: Ahimsa, Satyagraha, and social movements for women

\section{Pendahuluan}

Mohandas Kramchand Gandhi atau lazim dikenal sebagai Mahatma Gandhi merupakan bapak bangsa India. Sosok yang dalam hidupnya konsisten menggunakan pendekatan pantang kekerasan (ahimsa) dalam mewujudkan kemerdekaan India dari Kolonialisme dan Imperialisme Inggris. Selain dikenal sebagai pejuang tanpa kekerasan, Gandhi adalah sosok gigih membela serta memberikan transformasi sosial pada hak-hak kaum perempuan di India. Gandhilah 
yang mendudukkan kaum perempuan India sejajar, bahkan lebih tinggi, dengan kaum pria. Kata-kata Gandhi selalu bertenaga, didengar dan dilaksanakan pengikutnya, karena ia selalu memulai pembaharuannya dari dalam dirinya dan keluarganya sendiri.

Berangkat dari kesadaran bahwa perempuan memiliki kemampuan untuk ikut membangun negara dan bangsa, Mahatma Gandhi pernah mengatakan, upaya pertama yang mesti ditempuh oleh kaum perempuan adalah upaya semaksimal mungkin untuk membangkitkan kesadaran pemikiran kaum perempuan tentang kondisi yang menimpa mereka pada saat ini, sehingga harkat dan martabat kaum perempuan dapat ditingkatkan. Sesungguhnya, untuk dapat mewujudkan gagasan ini semata memerlukan kaum perempuan dalam jumlah yang tidak banyak, dan oleh karena itu kita akan berpikir bahwa kaum perempuan pada umumnya dapat melakukannya apabila mereka mencoba.(Gandhi 2011:4).

Apa yang diuraikan Gandhi tersebut tentunya terdapat beberapa hal yang dipahami, Pertama, perempuan banyak yang belum disiapkan untuk masuk ke ranah publik, mereka masih terpatri pada tugas rumah tangga. Kedua, perempuan harus mampu bersuara dan mengambil keputusan sehingga perannya akan berarti bagi pembangunan. Karena tidak pernah ada ditemukan fakta absolute yang menyatakan bahwa perempuan lebih bodoh atau tidak mampu menjadi pemimpin. Stereotipe gender hanya "buatan" dunia patriarki semata yang menyudutkan perempuan. Berkaitan dengan perkembangan zaman, masyarakat sekarang membutuhkan peran perempuan dalam segala aspek, pendidikan, sosial ekonomi, hukum, politik, dan lain-lain. Hal tersebut dipengaruhi oleh tuntutan bangsa-bangsa atas nama masyarakat global bahwa kemajuan suatu bangsa ditentukan bagaimana bangsa tersebut peduli dan memberi akses yang luas bagi perempuan untuk beraktifitas di ranah publik. (Ahdiah. 2013).

Pendekatannya berakar pada tradisi Hindu India dan mencakup seluruh aspek kehidupan sosial dan personal. Di mana,Gandhi berkata; saya sering menggunakan istilah pantang kekerasan untuk mencerminkan kombinasi dari anti melukai dengan energi positif dan tindakan komperhensif (Diana Francis:2002.8586). Dan ungkapan Gandhi tersebut dibuktikan dalam perjuangan, tingkah laku serta kehidupan keluarganya hingga kematiannya.

Gerakan sosial pantang kekerasan ini menyebar keseluruh negeri seperti api membakar padang rumput pada musim kering. Pada Januari 1922, 30 ribu rakyat India di masukkan ke penjara. Bahkan orang-orang India konservatif pun mulai merenungkan bahwa Gandhi selama ini benar, sikap pantang kekerasan dapat memberi mereka kemerdekaan penuh bagi India, di mana Gandhi menyeruka bahwa untuk mencapai kemerdekaan, rakyat perlu menetang hukum Inggris serta membangun ekonominya sendiri (Easwaran, 2008:104).

Disamping itu, gerakan pantang kekerasan Gandhi yang melawan Inggris tidak semata-mata bersifat politik, melainkan juga berhaluan ekonomi. Gandhi menyerukan kepada rakyat India, supaya mereka tidak lagi mengunakan pakaian Eropah, melainkan memakai pakaian dan kain buatan sendiri. Rakyat India harus membuat kerjinan sendiri, belajar kembali menggunakan Sjarka "perkakas pemintal benang" dan membuat Khaddar" kain yang dilakukan dengan memintal sendiri" disini Gandhi menyerukan, kenapakah hendak membeli kain dari Eropah untuk 
membuat baju, sedangkan mereka sanggup membuatnya rakyat India pernah turun temurun dari nenek moyang sampai anak cucunya membuat kain sendiri, tidak benar kalau mereka menghilangkan kerajinan nasional sendiri dan memajukan Industri Inggris. Kapas yang dijadikan benang, dikirim ke Inggris, setelah itu di bawah dan dijual kembali ke anak cucu India. Oleh karena itu Gandhi memobilisasi rakyat untuk memproduksi kain sendiri dengan memintal setiap hari di segenap penjuru India (Hatta, 1954:37).

Konsep dan teknik-teknik yang dikembangkan serta dimatangkan Gandhi dengan bereksperimen selama bertahun-tahun berakar dalam jiwa dan pikiran massa rakyat, mereka tahu apa yang diinginkan Gandhi untuk mereka lakukan. Gandhi percaya bahwa para pemimpin dapat melalui suatu pergerakan, jika pemimpin tersebut menginterpretasiakan dengan tepat keinginan rakyat. Gandhi sendiri mengatakan bawah, dia tidak pernah menciptakan sebuah situasi. Gandhi hanya merasakan secara insting apa yang sedang berkecamuk di hati massa rakyat dan baru kemudian Gandhi merumuskan sebuh program dan memberikan bentuk kepada apa yang sudah ada(Hatta, 1954:56).

Sebuah studi tentang Ahimsa dan Satyagraha jelas memperlihatkan bahwa gerakan yang dilakukan Gandhi itu sesuai dengan azas-azasnya. Ahimsa dan Satyagraha merupakan puncak dari perjuangan Gandhi. Dimana azas dan teknik organisasi untuk memobilisasi massa rakyat terbukti kebenarannya dengan jelas. Ahimsa dan Satyagraha mengkombinasikan tujuan jangka pendek dengan perspektif jangka panjang, yang lebih penting lagi Satyagraha membuktikan kebenaran metodanya untuk mempersatukan teori dengan cara-cara pergerakan sosial pantang kekerasan. Satyagraha membuktikan kekuatan metode Gandhi untuk melakukan penetrasi kepada rakyat walaupun di daerah-daerah agraris yang terkebelakang secara sosial dan politik, dan metodenya untuk melakukan pendekatan kolektif dan pendidikan gerakan sosial pantang kekerasan(Hatta, 1954:57).

Dalam pelaksanaan gerakan sosial pantang kekerasannya, Gandhi selalu menekankan kepada para pengikutnya bahwa, kolektifitas menjadi sesuatu yang penting. Maka, Gandhi menghimbau gerakan pantang kekerasan harus selalu hidup dalam sanubari setiap rakyat, baik itu, anak-anak, lak-laki dewasa maupun perempuan. Oleh karena itu, gerakan Gandhi tidak semata-mata direspon oleh kalangan terpelajar semata, tetapi menjadi kekuatan bagi seluruh rakyat India dalam upaya untuk membebaskan bangsanya dari penjajahan Inggris.

Berangkat dari konsep Gandhi tersebut, contoh yang kongkrit dapat di lihat melalui tulisan-tulisannya. Di mana, Gandhi menemui dirinya sendiri. Perjuangan yang paling hakiki adalah perjuangan moral, spiritual, sosial dan individual. Partisipasi aktifnya dalam politik merupakan sebuah perpanjangan kegiatan sosial dan komitmen individualnya; saya tidak bisa menjalankan kehidupan yang agamais jika saya tidak dapat mengidentifikasi diri saya dengan semua manusia, dan hal ini tidak dapat saya lakukan jika saya tidak ambil bagian dalam politik. Seluruh kegiatan umat manusia sekarang merupakan kesatuan yang tidak dapat dipecahpecahkan,politik memang sangat personal (Nandan, 2008:80).

Gandhi menambahkan Maksud dari perkatannya adalah, kalian akan merasa lebih kuat, bukannya lebih lemah karena telah meninggalkan pisau dan senapanmu. Jika mereka merasa lebih kuat. Pada bulan Desember 1921, Gandhi diinvestasikan 
dengan kewenangan eksekutif atas nama Kongres Nasional India. Di bawah kepemimpinannya, Kongres direorganisasi dengan konstitusi baru, dengan tujuan Swaraj (pemerintahan sendiri). Keanggotaan dalam partai dibuka untuk umum. Sebuah hirarki komite didirikan untuk meningkatkan disiplin, mengubah partai dari sebuah organisasi elit ke salah satu daya tarik massa nasional. Gandhi memperluas platform non-kekerasan untuk mencakup kebijakan swadeshi (gerakan yang menganjurkan agar menggunakan barang-barang buatan bangsa sendiri) - boikot terhadap barang-barang buatan luar negeri, terutama barang-barang Inggris. Terkait dengan advokasi ini adalah bahwa khadi (kain tenunan sendiri) dikenakan oleh semua orang India bukan buatan tekstil Inggris. Gandhi mendesak India dan laki-laki perempuan, kaya atau miskin, untuk menghabiskan waktu setiap hari khadi berputar dalam mendukung gerakan kemerdekaan (Nicholson, 1994:50).

Ini adalah strategi untuk menanamkan disiplin dan dedikasi untuk menyaring keluar mau dan ambisius, dan keterlibatan perempuan dalam pergerakan pada saat banyak yang berpikir bahwa kegiatan tersebut tidak kegiatan terhormat bagi perempuan. Selain memboikot produk-produk Inggris, Gandhi mendesak orangorang memboikot pendidikan dan orang yang bekerja di pengadilan hukum Inggris, untuk mengundurkan diri dari pekerjaan pemerintahnya. Hal ini yang dikenal dengan tiga pesan politiknya untuk rakyat India (Nicholson, 1994:44).

\section{Satyagraha dan Perjuangan Kaum Perempuan India}

Fase dramatis dalam perjuangan politik Gandhi dan masyarakat India ini diawali dengan peluncuran gerakan Satyagraha (kekuatan kebenaran) melalui ajakan Gandhi kepada warga India agar mereka mengolah garam sendiri dari air laut dan memboikot pajak garam yang diterapkan kepada warga India. Perjuangan ini diawali pada tanggal 12 Maret 1930, ketika Gandhi berangkat dari Sabarmati India bersama 78 sukarelawan menuju Dandi untuk memulai Satyagraha. Gandhi bertekad tidak akan kembali ke Ashramnya di Sabarmati (Ahmedabad) sampai kemerdekaan India terwujud. Gerakan kali ini lebih di kenal dengan Gerakan Swadeshi atau semangat Cinta Tanah Air. Di mana rakyat India diminta untuk memakai produk sendiri dan memperkuat basis ekonomi rakyat tanpa bergantung pada orang lain. Gerakan tersebut kemudian diikuti oleh seluruh warga India dan menyulut gerakan perlawanan anti kekerasan kepada pemerintah kolonial Inggris. Pemerintah Inggris kembali merespon gerakan tersebut dengan penangkapan-penangkapan terhadap para aktivis dan seluruh pemimpin Partai Konggres India, termasuk Gandhi (Allapatt,2005;22).

Inti dari Satyagraha adalah berpegang pada kebenaran, atau kekuatan jiwa. Dalam pelaksanaan Satyagraha, Gandhi menentang terhadap praktek kekerasan kepada lawan, sebaliknya ia harus menghentikan kesalahan lawan dengan kesabaran dan simpati, karena apa yang dianggap benar bagi seseorang dapat dianggap salah oleeh orang lain. Kesabaran berarti pengorbanan diri, jadi dalam ajaran Satyagraha berarti mempertahankan kebenaran bukan dengan membebani orang lain dengan penderitaan melainkan dengan membebani penderitaan kepada diri sendiri. Pada Satyagraha perlawanannya dilakukan dengan menderita sendiri atau pengendalian diri, seperti melalui puasa. Semenjak perlawanan dalam Satyagraha dialami melalui penderitaan diri sendiri yang merupakan senjata yang paling sesuai bagi kaum 
perempuan, banyak kaum perempuan di India di banyak instansi melebihi kaum lelaki mereka dalam menderita dan memainkan bagian yang mulia dalam kampanye. Pada masa perjuangan melawan pengusaan Inggris dapat disaksikan bahwa wanita India dalam banyak peristiwa mengungguli kaum prianya dalam menahan penderitaan dan bersama-sama kaum laki-laki (Hasiholan,2009:56-57)

Perjuangan Mahatma Gandhi ini dilandasi dari realitas soial perempuan pada masa itu di mana status perempuan lebih rendah dari kaum laki-laki, bahkan di kalangan masyarakat Hindu berkembang pemahaman bahwa seseorang tidak akan masuk surga tanpa anak laki-laki, dan untuk hal itu seorang suami bisa menikahi 2, 3, atau 4 istri.( Gandhi, 2002:189). Selain itu kebiasaan-kebiasaan di kalangan masyarakat Hindu seperti pernikahan dini, mengungkung perempuan pada bilik-bilik tersembunyi di rumah- rumah, ajaran sati, kondisi yang menyedihkan untuk para janda muda serta masih banyak kaum laki-laki yang memandang rendah kaum perempuan, hal itu semua membuat kaum perempuan India menjadi suatu golongan yang lemah, tertindas, tersingkirkan dan menjadi "warga kelas dua". Realitas kaum perempuan Hindu yang sangat mengenaskan tersebut yang akhirnya menyebabkan Gandhi tergerak untuk membuat perubahan-perubahan kearah positif bagi perempuan Hindu di India. (Hasiholan,2009:53-54)

Pada pemberontakan pertama kalinya ini masyarakat ini belum matang dalam perjuangan Satyagrahanya itu, maka terjadilah keributan dan pembantaian besar-besaran oleh tentara Inggris pada tanggal 13 april 1919 di Amritsar. Melihat kejadian tersebut, Gandhi menyerukan kepada seluruh wanita India agar mereka ikut terjun dalam perjuangan untuk menyelamatkan bangsa. Keterlibatan kaum wanita untuk bergabung dalam perjuangan tanpa kekerasan sangat di harapkan. Ratusan ribu wanita, yang sebelumnya tidak pernah keluar dari bilik-bilik tersembunyi didalam rumah mereka, ikut serta melakukan razia demi swaraj. Demikianlah Gandhi memulai revolusi sosial di India yang sama kuatnya dengan revolusi politik. (Hasiholan, 2009:60)

Gandhi menegaskan bahwa, tidak perlu meragukan terkait dengan satyagraha. Karena satyagraha adalah sesuatu yang benar mengahdapi berbagi persoalan. Bagi Gandhi, dalam praktiknya satyagraha mengisyaratkan adanya disiplin diri, kontrol diri, penyucian diri dan sebuah status sosial yang diakui seorang yang menjalankannya. Seorang penganut satyagraha tidak luput untuk membedakan antara kejahatan dengan pelaku-pelaku kejahatan. Tidak boleh memiliki perasaan iri hati, itikad buruk atau menaruh kebencian kepada pelaku kejahatan. Dia perlu menggunakan bahasa-bahasa yang terhadap orang yang pernah melakukan kejahatan, walaupun orang tersebut tidak pernah berhenti melakukan kejahatan. Ini merupakan pasal yang harus diyakini bahwa tidak ada seorangpun di dunia yang telah melakukan kejahatan, kecuali dia dapat disadarkan dengan cinta (Gandhi, 2011:124125).

Gerakan satyagraha yang digagas Gandhi kemudian menjadi salahsatu bagian penting dari keterlibatan aktif kaum perempuan india dalam setiap proses perubahan sosial yang terjadi pada masa itu. Semangat cinta dan penyucian diri tersebut dipraktekan oleh kaum perempuan dengan menjadi bagian penting sebagai seorang satyagrahi (penyebuat sebagai pengikut ajaran satyagraha). Keterlibatan kaum perempuan tersebut diimplementasikan melalui rangkaian aksi tanpa 
kekerasan. Yakni aksi diam dan aksi tidak demonstratif dalam memperjuangkan kebenaran dan disertai dengan cinta. Karena bagi Gandhi, gerakan dengan menggunakan cinta akan jauh lebih bertahan lama (permanen) dan menampakkan hasil kekal daripada pidato-pidato atau aksi-aksi lainnya yang menonjolkan pertunjukkan-pertunjukkan yang mencolok. Disamping itu bagi Gandhi, satyagraha dapat diterapkan dengan menggunakan aksi yang nyata, contoh dengan memobilisasi opini publik untuk mentang kejahatan, melakukan kampanye yang melawan penyelewengan di masyarakat sampai tidak ada orang yang punya keberanian untuk melakukan kejahatan secara terbuka di dalam masyarakat (Gandhi, 2011: 126).

Relasi antara gagasan satyagraha Gandhi dengan semangat perubahan kaum perempuan India dengan merespon tindak kejahatan dalam masyarakat. sebagaimana diamati Gandhi sebagai bentuk yang diskrimiasi terhadap kaum perempuan. Persoalan pernikahan dini dan status janda yang secara sosial kaum perempuan terdiskriminasikan, di mana mereka tidak diijinkan untuk menikah kembali. Disamping itu, kaum perempuan India dianggap sebagai kelas nomor dua dan perempuan terbatas dalam proses akses terhadap pendidikan. Akses terhadap pendidikan secara yang politis di dominasi oleh kaum laki-laki, dan tentunya berbasis pada status kelas sosialnya. Di mana, kelas yang lain tidak memiliki aksesnya terhadap pendidikan. Inilah persoalan yang serius bagi Gandhi dan tentunya bertentangan dengan semangat satyagraha yang dia gaungkan.

Kaitan dengan persoalan yang dialami kaum perempuan tersebut, Gandhi menegaskan bahwa kaum perempuan itu seperti yang pernah dilukiskan dalam bahasa Inggris, istri umat manusia. Bagi Gandhi, setiap perempuan modern memiliki arti yang spesial. Semua perempuan yang mempunyai pendidikan dalam bahasa Inggris tidak secara otomatis dikelompokkan yang perempuan modern. Saya mengetahui bahwa banyak diantara mereka yang sama sekali tidak tersentuh oleh semangat perempuan modern. Penegasan Gandhi tersebut merupakan satu pandangan yang sosiologis bahwa, kaum perempuan India dalam kehidupannya tidak perlu meniru gaya hidup kaum perempuan modern. Karena, meniru gaya modern tentu akan mempersulit kehidupan mereka. Karena Tuhan hanya akan membantu orang-orang yang menolong dirinya sendiri. Para perempuan harus belajar tentang seni melindungi dirinya sendiri terhadap perilaku kurangajar para kaum laki-laki. (Gandhi, 2011:158).

Fokus utama Gandhi terhadap gerakan kaum perempuan tentunya mempunyai alasan tersendiri. Di mana, faktor kelaparan yang melanda jutaan orang India karena ketiadaan makanan dan pekerjaan. Maka, melalui perhiasan yang dikenakkan oleh kaum perempuan perempuan tersebut untuk disumbangkan sebagai dana perjuangan dan kaum perempuan tidak perlu hidup dengan perhiasan yang berlebihan. Dengan kesadaran kaum perempuan, maka lahirlah gerakan khadi (kain tenunan tangan) di kaum perempuan India memobilisasi diri dalam gerakan ini dengan memfokuskan pada pemberdayaan ekonomi rakyat yang dengan sadar memintal benang dan membuat dan memproduksi pakaian sendiri. Maka, menurut Gandhi gerakan ini memiliki pengaruh moral yang besar, dan keterlibatan anak-anak perempuan India yang kaya dalam gerakan khadi ini akan meningkatkan bangsa dan menyelamatkan orang-orang yang kelaparan (Gandhi, 2011:203-204). 
Gerakan khadi dan sikap kesukarelaan kaum perempuan menyumbangkan perhiasan itan permatanya yang berharga sebagai modal perjuangan. Hal ini menurut Gandhi merupakan gerakan permurnian diri. Di mana, pemberian perhiasan oleh kaum perempuan maupun kaum laki-laki dengan sukarela dan rasa bangga hal tersebut memiliki manfaat nyata bagi masyarakat. disisi lain, Gandhi mensyaratkan bahwa sumbangan untuk modal perjuangan tidak semata perhiasan namun diganti dengan cara lainnya,seperti gerakan khadi sebagai alternatif memobilisasi dan mengakomodir semangat perjuangan kaum perempuan India. Maka, dengan alternatif merawat semangat kaum perempuan tersebut, roda pemintal sebagai modal perjuangan masif dan efektif Gandhi untuk mendapat simpati kaum perempuan dan kaum pria India.

\section{Relasi gerakan Ahimsa dan Partisipasi Politik Kaum Perempuan}

Ahimsa atau Pantang kekerasan, sebagai sebuah strategi untuk melakukan perubahan sosial sudah berkali-kali terbukti efektif dan dianggap berbahaya oleh lawan. Gerakan ini bukan menjadi metode yang terlalu idealistis, tidak berbahaya, atau tidak bermanfaat sama sekali. Pantang kekerasan mendatangkan dampak yang kurang menyenagkan terhadap kekuatan-kekuatan yang bersifat menindas (opresif) dan golongan vested-interest yang tampaknya tidak menyadari bahwa mereka berpijak di atas struktur yang tidak adil dan tidak merata. (Mittal, 2008;60).

Keyakinan yang di pakai Gandhi untuk mencoba menghapuskan praktek praktek kekerasan di muka bumi, ini dinamakannya Ahimsa. Ahimsa secara sederhana dipraktekkan dalam kehidupan sehari-hari, sebagaimana pada praktiknya Gandhi menamainya Ahimsa atau pantang kekerasan adalah tindakan yang berasal dari pemikiran bahwa manusia dapat menyelesaikan suatu persoalan pantang kekerasan sebagai alternatif dari pada melalui jalan kekerasan. Hal ini sebagaimana sering dilihat dengan adanya musyawarah, diplomasi, diskusi, dan semacamnya untuk memperoleh apa yang dinamakan titik temu yang mana diharapkan untuk tidak merugikan ataupun menindas salah satu pihak. Ahimsa menghendaki penderitaan diri secara sadar sebagai suatu cara yang lebih tinggi dari pada cara yang hendak membalas kekerasan dengan kekerasan (Pleysier,1952:16).

Gandhi menolak aturan diskriminatif dengan mogok makan, berjalan kaki bermil-mil, membuat garam sendiri ketika semua rakyat harus membeli garam dari pemerintah Inggris, dan sebagainya. Bagi Gandhi, hasrat seksual merupakan sumber dari kejahatan dan cenderung mementingkan diri sendiri, yaitu nafsu, amarah, dan penyerangan. Hasrat seksual dapat ditaklukkan melalui penolakan terhadap adanya pamrih yang selalu mengikuti perbuatan, untuk itulah Gandhi bertekad menjalani prinsip menahan hawa nafsu atau disebut bramkhacharya. Ketiadaan pamrih dapat dilakukan bila jiwa terikat pada prinsip Kebenaran Ilahiah. Inilah prinsip satyagraha, yaitu kepercayaan bahwa jiwa dapat diselamatkan dari kejahatan dunia, dan juga dapat memberikan pertolongan, sejauh jiwa itu senantiasa berada dalam pencariannya terhadap Tuhan melalui kebenaran dan hanya kebenaran.

Untuk memdalami konsep atau gagasan perjuangan Gandhi yang dilakukan di India. Dengan bebasis pada realitas kehidupan masyarakat India yang terdiskriminasikan dan penindasan pada masa kolonialisme Inggris. Disisi lain, persoalan diskriminasi dan penindasan serta eksploitasi dari pihak Inggris, ahimsa 
dan syatgraha menjadi alternatif penyatuan masyarakat India, baik kalangan elit politik, pengusaha, kaum laki-laki dan perempuan kelas bawah tergerak untuk secara bersama melawan intervensi pihak asing tersebut. Guna memahami dasar pijakan ajaran Gandhi dalam perjuangan menuju kemerdekaan India dapat dilihat dari tabel di bawah ini:

Tabel: Dasar pijak ajaran Gandhi

\begin{tabular}{|l|l|}
\hline Pertama & Kedua \\
\hline $\begin{array}{l}\text { Kemerdekaan hanya dapat dimulai } \\
\text { dari kemandirian dan kedewasaan } \\
\text { berpikir serta bersikap }\end{array}$ & $\begin{array}{l}\text { Perkembangan dan kemajuan akan tidak } \\
\text { dapat diperoleh melalui usaha perlawanan } \\
\text { (konsesi-konsesi) dan reformasi } \\
\text { konstitusional, namun melalui perjuangan } \\
\text { rakyat secara bersama atau kolektif } \\
\text { dengan membutuhkan kekuatan cinta dan } \\
\text { kerelaan dari massa rakyat }\end{array}$ \\
\hline
\end{tabular}

Sumber: diolah dari Mittal. 2008:60

Memahami apa yang menjadi basis dari ajaran Gandhi ini. Di mana, Gandhi menekankan bahwa pentingnya semangat patriotisme oleh para individu dalam mewujud kemerdekaan dan kesejahteraan. Proses mewujudkan kemerdekaan dan kesejhateraan rakyat, bagi Gandhi dapat di implementasikan melalui kemandirian individu dan kedewasaan berpikir serta bersikapnya. Sehingga, masing-masing individu-individu harus mampu menyalurkan hasrat negatifnya pada tindakantindakan positif. Kedua, Gandhi meyakini bahwa perkembangan dan kemajuan akan diperoleh tidak melalui usaha perlawanan (konsesi-konsesi) dan reformasireformasi konstitusional, tetapi melalui perjuangan yang dilakukan oleh rakyat sendiri secara bersama atau kolektifitas. Untuk dapat membangkitkan kebersamaan itu dibutuhkan kekuatan cinta dan kerelaan untuk mengalami penderitaan bersama massa rakyat. (Mittal,2008:60).

Secara harfiah, Ahimsa memiliki makna tidak menyerang atau tidak membunuh. Ahimsa merupakan ajaran klasik agama Hindu dan merupakan prinsip etis yang umurnya sudah sangat tua. Tidak menyerang, tidak melukai atau tidak membunuh. Hal ini tidak terbantahkan bahwa hal tersebut memang merupakan bagian dari praktik etis dari Ahimsa, yang kemudian populer dikenal dengan makna pantang kekerasan. Ahimsa bukan sesuatu yang bersifat mentah dan kasat mata. Sepatutnya tidak perlu diragukan bahwa tidak melukai mahluk hidup adalah bagian dari ajaran Ahimsa. Ahimsa lebih menekankan pada makna penolakan atau penghindaran secara total terhadap semua keinginan, kehendak atau tindakan yang mengarah pada bentuk penyerangan atau melukai.

Dalam bentuk positif nya, Ahimsa adalah cinta, karena hanya ada satu cinta yang muncul secara spontan dan memukinkan sesorang bertindak selaras dengan pikiran dan hatinya. Gandhi menambahkan, pantang kekerasan adalah cinta. Pantang kekerasan itu betindak menyatu dalam diam, nyaris terselubung dalam kerahasiaan sebagaimana yang dilakukan cinta.( Alappatt, 2005:61). Sejak dibebaskan dari penjara pada bulan Mei 1924, Gandhi pada prakteknya telah meninggalkan dunia politik dan memusatkan perjuangannya pada program-program konstruktif, yang 
disebutnya sebagai juga penting untuk membangun bangsa dari bawah sampai atas (bottom up). Dalam masa ini Gandhi banyak berkunjung ke desa-desa di seluruh India. Demikian pula pada periode yang sama Gandhi dalam setiap pidato-pidato dan tulisan-tulisannya, Gandhi berulang kali menyebutkan lima tema penting, yaitu; alat pemintal, ketidaktergantungan pendidikan dasar, peningkatan derajat wanita untuk menopang masyarakat yang sehat dan kuat.

Dalam ajaran Gandhi, nilai-nilai Ahimsa menjadi basis dan karakter utama seluruh pencariannya atas kebenaran. Ajaran ini tercermin dalam sikap bahwa amal perbuatan harus didasarkan dan diilhami oleh semangat pantang kekerasan, yakni cinta untuk mencapai konsep ini. Di mana, seseorang baik kaum laki-laki maupun perempuan harus meleburkan dalam proses pencarian kebenaran secara total dan terus menerus atau bersifat tanpa henti atau transformatif. Proses partisipataif tersebut bukan sesuatu hal yang dilakukan secara main-main, tetapi merupakan proses yang melibatkan keseluruhan dan keutuhan segenap aktivitas manusia, baik aktivitas sosial, politik, hukum maupun kebudayaan.

Keterkaitan dengan semangat pantang kekerasan yang totalitas yang pada hakikatnya mentransformasikan nilai-nilai ahimsa dalam relaitas gerakan politik kaum perempuan. Gandhi mensyaratkan kaum perempuan harus meninggalkan tradisi sebagai penjaga rumah atau kodrat mengasuh anak. Bagi Gandhi, kaum perempuan India terpaksa menarik purdahdan maju ke depan untuk berjuang demi bangsa. Mereka melihat bahwa bangsa memerlukan sesuatu hal yang lebih daripada perawatan mereka terhadap rumah. Mereka membuat garam secara ilegal, menjagajaga terhadap perdagangan baju yang di impor dari luar negeri serta aktif dalam kampanye melarang peredaran minuman keras. Di mana, tengah malam kaum perempuan mengejar para pemabuk dengan berani dan pengabdian di hati mereka. Perempuan Barat mencoba berlomba-lomba dengan kaum pria yang menyukai praktik kekerasan dan mengirim suami dan anak-anak mereka untuk datang membunuh, mereka tidak akan mendapatkan pelajaran dari kaum perempuan India yang anti kekerasan dan berani(Gandhi, 2011:34-35).

Memahami berkembangnya gerakan perempuan di India dengan mengedepankan nilai-nilai pantang kekerasan sebagaimana yang dianjurkan Gandhi. Secara politik, menjadi salahsatu keberhasilan Gandhi melakukan transformasi gerakan sosial pantang kekerasan. Dalam perkembangannya, gerakan sosial kaum perempuan di India merupakan bagian dari bentuk partisipasi politik yang mereka lakukan. Bentuk partisipasi politik perempuan secara aktif dengan melakukan praktik yang transformatif atas nilai ahimsa memposisikan perempuan setara dengan kaum pria. Pada praktik gerakan perempuan yang bergulir tidak berbasis pada semangat perjuangan kelas, namun apa yang dilakukan oleh kaum perempuan pada masa itu menunjukkan bentuk perlawanan mereka terhadap ketidakadilan yang mereka alami dalam masyarakat. Bila di pelajari secara sosiologis, bahwa sistem kasta yang menjadi bagian dari struktur sosial masyarakat India dalam realitasnya menimbulkan ragam parsoalan yang menyulitkan mereka untuk bersatu, misal; klasifikasi status perempuan yang berbeda antar kasta dan diskriminasi terhadap perempuan terkait dengan akses terhadap pendidikan dan akses terhadap sumber ekonomi, seperti tanah dan sumber daya mereka miliki yang dikuasai oleh pihak kolonial Inggris. 
Selaras dengan partisipasi politik yang dipraktikkan oleh kaum perempuan India tersebut, menurut Karl Marx, partisipasi politik yakni perbedaan kelas tidak berakhir dengan diumumkannya pembentukan negara buruh, karena yang terjadi kemudian adalah pengaturan kerja (yang sama oleh kekuatan yang berbeda), persoalan terpenting dalam politik kelas yakni bukan sekadar memperkuat bargaining power buruh dihadapan pemilik modal atau kapital, tetapi menghapus hubungan menindas yang memaksa orang bekerja melalui bentuk komoditi. Pergulatan itu, seperti ditunjukkan Marx, tidak semata terjadi pada situasi kapitalisme. Perjuangan untuk mempertahankan tanah yang diserobot kapital adalah perlawanan terhadap ekspansi hubungan yang menindas itu dan sama pentingnya dengan perjuangan buruh yang menuntut kenaikan upah maupun berhimpun dalam koperasi yang mencari jalan alternatif di luar bentuk komoditi untuk memenuhi kebutuhan hidup kemunitasnya. (Kristeva,2011;370).

Partisipasi politik yang dipahami dari konsep Marx seperti yang di gambarkan oleh Nur Sayyid Santoso Kristeva (Kristeva,2011;370) dapat dipahami bahwa terkait dengan politik kelas. Dari politik kelas ini, dalam prakrik partisipasi politik tentunya merupakan bagian dari tugas organisasi partai politik. Menurut Surbakti, (Surbakti,2010;113-130) melalui partai politik maka kegiatan setiap warga bangsa akan lebih diakui pemerintah daripada kegiatan-kegiatan politik yang dilakukan setiap rakyat yang lebih bersifat individu. Melalui partai politik semua politisi diberi kesempatan yang sama untuk berekpresi berdasarkan aturan main yang disepakati bersama lewat partai politik.

Memahami apa yang diuraikan Marx, bahwa perjuangan yang dilakukan oleh kaum perempuan tersebut merupakan bagian dari cara mereka untuk mempertahankan hak mereka yang dalam hal ini dikuasai oleh pihak kolonial Inggris. Maka oleh Marx ditegaskan bahwa apa yang dilakukan oleh kaum perempuan sama dengan perjuangan buruh di Eropa yang menuntut kenaikan upah maupun berhimpun dalam koperasi yang mencari jalan alternatif di luar bentuk komoditi untuk memenuhi kebutuhan hidup kemunitasnya. Dan ada perbedaan dalam gerakan perempuan India mengilhami nilai ahimsa yang dianjurkan Gandhi sebagai roh perjuangan mereka. Sehingga aksi-aksi yang mereka lakukan tidak bertumpu pada satu ruang. Dengan dukungan dan pendampingan politik yang secara rutin diapresiasikan Gandhi terhadap gerakan perempuan serta mendorong partisipasi politik kaum perempuan aktif dan mempunyai pengaruh di partai kongres dan parlemen.

Gandhi dengan keyakinan politik yang teguh mendorong kaum laki-laki yang aktif dalam partai kongres untuk mempertahankan keyakinan ahimsa-nya dan melaksanakan program pantang kekerasan, maka secara otomatis kaum perempuan akan berubah dan mampu melakukan banyak perubahan. Karena menurut Gandhi, kaum perempuan lebih tepat daripada kaum laki-laki untuk mengekplorasikan aksi dan berani secara ahimsa. Dengan keberanian untuk mengorbankan dirinya, perempuan itu sesungguhnya lebih tinggi derajat daripada kaum pria (Gandhi, 2011:40). Sebagaimana prinsip dasar dari gagasan Ahimsa adalah penghormatan tertinggi terhadap setiap manusia tanpa memandang apa yang telah dia dilakukan. Gandhi menjelsakan dan menekankan hal tersebut secara khusus dan berulang-ulang, utamanya dikaitakan dengan konteks perjuangan meraih kemerdekaan di mana 
pantang kekerasan benar-benar harus diuji dalam skala yang luas dan dilakukan secara terus-menerus. Sehingga prinsip pantang kekerasan tidak berkutak pada membalas kekerasan dengan kekerasan semata, di mana ada nilai yang lebih etis bagi Gandhi yang bisa di pakai sebagai suatu peneguhan diri dengan berpuasa dan bahmacarya.

\section{Transformasi Gerakan Sosial Gandhi dan masa depan perempuan}

Pengaruh pikiran dan ajaran Gandhi mengakar dalam jiwa anak bangsa India. Hal tersebut tergambarkan pada setiap kegiatan ahimsa dan satyagraha dijadikan suatu bahan pelajaran untuk melihat lebih jauh lagi apa sebenarnya hak manusia dan mengapa manusia memiliki hak yang sama dalam kehidupan. Di satu sisi, ajaran-ajaran Gandhi merupakan ajaran yang praktis, sedangkan di sisi lain filosofis. Sebab, ajaran-ajarannya menyangkut kepada hal-hal dasar yang terdapat dalam diri manusia. Gandhi mempercayai bahwa Tuhan ada di dalam kebenaran, maka Gandhi mengharapkan bahwa setiap manusia dapat mencapai pemahaman akan kekuatan kebenaran yang sejati dan kebaikan-kebaikan yang melingkupi ajaran agama dan nilai kemanusiaan (Prana, 2010: 136).

Ahimsa sebagai roh pergerakan kaum perempuan dan dilihat kala Panitia kerja Konferensi seluruh perempuan India melaksanakan pertemuan di Abbottabad. Ini merupakan pertemuan perdana dan dalam pertemuan terebut, tidak mengenal berbedaan kasta dan perbedaan agama. Kaum perempuan Muslim, Sikh dan Hindu membaur bersama-sama secara bebas. Panitia merumuskan beberapa resolusi:

1. Menyerukan kepada seluruh kaum perempuan di dunia bahwa peperangan adalah jalan yang salah, tidak menyelesaikan perselisihan dan penderitaan dan menjadi bebas untuk menuju perdamaian dunia.

2. Pantang kekerasan sebagai jalan salahsatunya dan efektif untuk menjamin perdamaian dunia. Mendorong semangat tradisi kaum perempuan untuk secara kolektif merasaskan penderitaan dan menjaga kehormatan kaum perempuan di seluruh dunia serta mengemban amanah cita-cita perdamaian dunia.

3. Pengakuan utama status kemerdekaan India. Sebagai pencapaian tujuan dan kemerdekaan segala bangsa dan demokrasi dunia (Gandhi,2011:4142).

Tiga resolusi politik yang dilahirkan dari pertemuan kaum perempuan tersebut merupakan buah dari fokus perjuangan Gandhi untuk menciptakan tatatan masyarakatnya yang menjunjung nilai-nilai keadilan. Sebagai pejuang anti kekerasan, Gandhi berpegang teguh dan mengajarkan ajaran cinta kasih atau dikenal dengan ahimsa dan ajaran satyagraha. Keduanya menjadi landasan gerakan perjuangannya. Ahimsa merupakan ajaran anti kekerasan yang mengandung makna cinta tak terhingga, dan kesanggupan tanpa batas untuk menderita. Sedangkan satyagraha adalah berpegang teguh pada kebenaran, atau kekuatan jiwa. Dengan demikian, introspeksi diri akan selalu ada sebab kebenaran ada atau inheren di dalam diri kita, bukan sesuatu di luar diri kita.

Kedua ajaran Gandhi tersebut mewujud sebagai kontribusi Gandhi dalam pembebasan perempuan dari liang ketertindasan. Melalui ajaran itu pula, membangkitkan kesadaran perempuan dan laki-laki menjadi hal yang mendesak, 
karena kesadaran itulah yang akan melahirkan kekuatan dalam diri perempuan untuk menepis segala praktek penindasan dan melindungi dirinya sendiri. Bukan sesuatu yang tidak mungkin, praktek penindasan ini ada dan masih dipraktekkan di tempat atau daratan lain. sehingga permasalahan ini bukan persoalan yang hanya terkotakkan pada masyarakat India, sehingga menyuarakannya secara terus menerus adalah hal yang paling penting bagi Gandhi untuk memunculkan kesadaran publik, atau masyarakat di belahan bumi manapun.

Sumbangan Gandhi yang terbesar bagi kemanusiaan adalah pesannya mengenai Ahimsa (non-kekerasan) sebagai jalan menuju perdamaian, keadilan dan Tuhan. Gandhi menjalani dengan serius perintah-perintah Alkitab, "Jangan membunuh" dan "Kasihilah musuh- musuhmu," bersama-sama dengan tradisi Hindu tentang ahimsa (tidak membunuh), dan menerapkan penolakan terhadap kekerasan ke dalam hati dan kehidupannya demikian pula kepada Afrika Selatan, India dan seluruh dunia. Tetapi dia mengajarkan pula bahwa non-kekerasan bukan hanya menolak membunuh: itu adalah tindakan kasih dan kebenaran sebagai sebuah kekuatan perubahan sosial yang positif. Malahan, dia menegaskan bahwa nonkekerasan adalah kekuatan yang paling aktif. (Hasiholan, 2009:54)

Ahimsa berarti cinta tak terhingga dan ini berarti kesanggupan tanpa batas untuk menderita. Gandhi menyebutkan bahwa suatu fitnah bila menyebut kaum perempuan sebagai makhluk yang lemah. Tindakan semacam itu merupakan tindakan yang tidak adil dari kaum laki-laki terhadap kaum perempuan. Bila yang dimaksud hanya terbatas pada kekuatan kasar, memang kaum perempuan kurang kasar daripada kaum laki-laki, tetapi bila yang dimaksudkan adalah kekuatan moral, kaum perempuan mengungguli kaum laki-laki. Bukankah intuisi kaum perempuan jauh lebih halus, bukankah kaum perempuan lebih rela mengorbankan diri, lebih kuat bertahan dan lebih berani. Tanpa adanya kaum perempuan kaum laki-laki tidak mungkin ada.

Gandhi berkata; Manusia dan perbuatannya adalah hal yang berbeda. Suatu perbuatan baik akan menimbulkan kebaikan, dan perbuatan jahat akan menimbulkan keburukan. Tetapi sang pelaku perbuatan tersebut, apakah perbuatan baik ataupun jahat, senantiasa berhak untuk mendapatkan pernghormatan sebagimana pantas dia menerimannya ( Alappatt, 2005:20). Perlawanan terhadap sistem tindak kejahatan atau tatanan sistem yang bersifat menindas harus dipandang secara jelas dan jernih. Dan para pelaku (actor) gerakan sosial harus benar-benar mampu memisahkan antara pelaku dari perbuatan tertentu atau benar-benar mampu memisahkan antara pelaku atau sang kreator dari sebuah sistem.

\section{Simpulan}

Pada praktiknya ajaran dan gagasan Gandhi yang terkait dengan satyagraha dan ahimsa merupakan salahsatu roh perjuangan bagi pergerakan kaum perempuan India. Relasi antara kaum laki-laki dan kaum perempuan dalam kehidupan masyarakat semata bertumpu pada persoalan peran dan kesetaraan. Dalam kajian gender dan politik, relasi perempuan dan laki-laki sebagaimana yang dipraktikan Gandhi merupakan pembuktian bahwa pemisahan status sosial dan kelas sosial justru membuat persoalan baru dalam masyarakat atau secara umum mengkapling ruang kehidupan yang secra berbeda di dalam masyarakat. Pada akhirnya perjuangan 
menuju India merdeka menjadi tanggungjawab bersama, secara mayoritas harapan diberikan kepada kaum laki-laki.

Ahimsa dan syartagarah sebagai solusi penyatuan dari Gandhi bermakna sebagai cinta yang tertinggi atau Dharma yang paling agung. Semangat bersama antara kaum laki-laki dan kaum perempuan menjadi satu bagian terpenting dalam perjuangan kemerdekaan India. Kedua gagasan Gandhi tersebut menjadi penguat dalam realitas masyarakat yang menderita buah dari kolonialisme Inggris. Keseriusan Gandhi dalam melakukan kampanye damai dari desa ke kota di seluruh India guna menyadarkan kaum perempuan membuahkan hasil yang mengagumkan dan dalam perkembangannya, kaum perempuan India terlibat aktif di dalam Kongres dan dunia perpolitikan di negaranya.

Kampanye damai yang digaungkan Gandhi mendorong semangat kaum perempuan India menyerukan kepada seluruh kaum perempuan di dunia bahwa peperangan adalah jalan yang salah, tidak menyelesaikan perselisihan dan penderitaan dan menjadi bebas untuk menuju perdamaian dunia. Pantang kekerasan sebagai jalan salahsatunya dan efektif untuk menjamin perdamaian dunia. Mendorong semangat tradisi kaum perempuan untuk secara kolektif merasaskan penderitaan dan menjaga kehormatan kaum perempuan di seluruh dunia serta mengemban amanah cita-cita perdamaian dunia. Pengakuan utama status kemerdekaan India. Sebagai pencapaian tujuan dan kemerdekaan segala bangsa dan demokrasi di seluruh dunia.

\section{Daftar Pustaka}

\section{Buku}

Alappatt, Francis, 2005. Mahatma Gandhi, Prinsip-prinsip pemikiran Politik dan Konsep Ekonomi, Bandung, Penerbit Nusa Media.

Diana Francis, 2002. Teori Dasar Transformasi Konflik Sosial, Yogyakarta, Penerbit Quills.

Eknath Easwaran, 2008. Badshas Khan Kisah Pejuang Muslim Antikekerasan Yang Terlupakan. (Yogyakarta, Penerbit BENTANG.

Galtung. Johan, 2002. Kekerasan Budaya; dalam “Teori-teori Kekerasan”. Jakarta. Penerbit Ghalia Indonesia.

Gandhi, Mahatma, 20011. Kaum Perempuan dan Ketidakadilan Sosial. Yogyakarta:Pustaka Pelajar.

Mohammad Hatta, 1954. Ekonomi Sjarka dan Khaddar Alias Politik Perekonomian Mahatma Gandhi; Lihat. Dalam Kumpulan Karangan/ (Jakarta: Balai Buku Indonesia. 
Nicholson, Michael, 1994. Mahatma Gandhi, Pahlawan yang membebaskan India dan Memimpin dunia dalam perubahan tanpa kekerasan, Jakarta: PT Gramedia,

Pleysier. A, Gandhi Pelopor Kemerdekaan India. Jakarta: PENERBIT DJAMBATAN,

Prana. Wied, 2010. Biografi Singkat Mahatma Gandhi 1869-1948: Gandhi Manusia bijak dari Timur, Yogyakarta: Garasi.

Santoso Kristeva, Nur Sayyid, 2011. Negara Marxis dan Revolusi Proletariat, Yogyakarta: Pustaka Pelajar.

Surbakti, Ramlan. 2010. Memahami Ilmu Politik, Jakarta: Grasindo.

\section{Jurnal:}

Ahdiah, Indah. JURNAL ACADEMICA Fisip Untad VOL.05 No. 02 Oktober 2013.

Hasiholan, Perempuan Hindu dalam Pemikiran Mahatma Gandhi.Jakarta. UIN SYARIF HIDAYATULLAH.

Mittal, Susil. 2008. Non Kekerasan dalam Dunia Yang Keras; dalam India Perspectives (New Delhi, India Perspectives, Januari

Nandan, Satendra. 2008. Mahatma Gandhi Membaca dan Menulis. (New Delhi: India Perspectives, Januari 